\title{
COLLABORATIVE GOVERNANCE IN THE REDUCTION OF EARTHQUAKE AND TSUNAMI DISASTER RISKS IN BENGKULU CITY
}

\author{
Sri Indarti and Juim \\ State Administration Lecturer, Faculty of Social and Political Sciences \\ Muhammadiyah University Bengkulu, Indonesia \\ sriindarti@umb.ac.id
}

\begin{abstract}
This study analyzes Collaborative governance in the earthquake and tsunami Disaster Risk Reduction Policy (DRR). Collaborative governance analysis in disaster risk reduction policy uses Ratner's Collaborative Governance Stages (2012) theory, which includes Identifying Obstacles and Opportunities, Debating Strategies for Influence and Planning Collaborative Actions

Disaster Risk Reduction for Earthquake and Tsunami Disasters has been carried out in the City of Bengkulu which is located on the west coast of the island of Sumatra. Various institutions have developed DRR, with their respective patterns and limited coordination. Collaborative governance foundation has been carried out and needs to be developed strategically as an alternative implementation and development of more effective policies and management.

The findings in this study that Collaboration on DRR The earthquake and tsunami in Bengkulu City were in the pilot stage, which provided the initial foundation for developing DRR policy implementation. There are obstacles in DRR implementation and management, which require strategic collaboration for the development of DRR effectively and equitably and continuously. Collaborative follow-up needs to be done with the establishment of a permanent forum that is needed flexibly, by avoiding a strict hierarchical structure or using organization horizontally, so that it can accommodate and utilize various stakeholders' potential optimally.
\end{abstract}

Keywords: Collaborative government, Disaster Risk Reduction (DRR)

\section{INTRODUCTION}

Disaster Risk Reduction (DRR) as the latest paradigm in disaster management has been developed in Bengkulu in the last decade by various institutions, including government agencies, the private sector, the community and Non-Governmental Organizations (NGOs). Public administrators have an important role in the implementation of DRR policies and management in the region.

Public administrators with all their bureaucratic activities have a responsibility to protect the community from disasters through appropriate policies for security, service and disaster preparedness efforts. Disaster management through the right policies becomes the affairs of the government apparatus both at the Central and Regional levels, in accordance with the context of 
threats, vulnerabilities and capacities faced. (Indarti, 2017). The earthquake and tsunami DRR program in the city of Bengkulu, which was developed by various groups, was accompanied by an awareness of the vulnerability of the city of Bengkulu, which was in two sources of the earthquake, namely from the Land and Sea.

Vulnerability to earthquakes, tsunamis and Goro (small tsunamis) is increasing with the Bengkulu position which has a complex geological order because it is in the collision of 2 large tectonic plates namely the Indo-Australian plate in the South and the Eurosia plate in the north which is marked by the presence of centers earthquake tekt0nik (Indarti, et all, 2017: 1)

Vulnerability to earthquakes and tsunamis, among others, can be observed from the statement of the Head of the Bengkulu BMKG, that "almost every day there are small earthquakes. Even so, the community is advised not to worry because the presence of small earthquakes would be better to appear to anticipate earthquake energy concentrations. The existence of small earthquakes below 5 SR means that the earthquake has often released energy so that it will minimize the appearance of larger earthquakes ... "Bengkulu Ekspress, March 9, 2011: 5)

Effective collaboration is realized from various processes such as communication, cooperation, and flexibility. Collaboration is a condition where all stakeholders will automatically contribute to each other. (http://khadafidsociality.bilogospot.co.id/2011/07). This study examines the collective governance stages in DRR in the City of Bengkulu.

\section{LITERATURE REVIEW}

A. Collaborative governance

Collaborative govenance is essentially a management process and the formulation of public policy decisions that involve actors who constructively come from various levels, both elements of government and or public institutions, private institutions, and communities that collaborate to achieve public goals.

Ansel and Gash (2007: 543) state that Collaborative governance is a governance arrangement where one or more public institutions directly involve non-government actors in a collective policy-making process that is formal, consensus-oriented and consultative in order to create or implement policies. public, managing programs or public assets. Collaborative governance is a new strategy in governance that makes various policy makers gather in the same forum to create a joint consensus. 
Collaborative governance develops in the era of the concept of governance, where the government is only one of the actors in public policy and public services. The government is

not the sole implementer of a good bureaucracy but there are other stakeholders, both private sector and community.

Collaborative governance is an instrument used to overcome a problem, which creates "shared ownership" of the problem. Various actors have different perspectives in seeing problems, so collaborative governance acts as an intermediary so that actors can formulate common understanding of a problem (Ansell, 2014: 172)

Collaborative governance has stages, where Ratner (2012: 5) states three focus phases or stages which are collaboration processes in governance, which include Identifying Obstacles and Opportunities, Debating Strategies For Influence and Planning Collaborative Actions. Ratner's stages can be seen in the following figure:

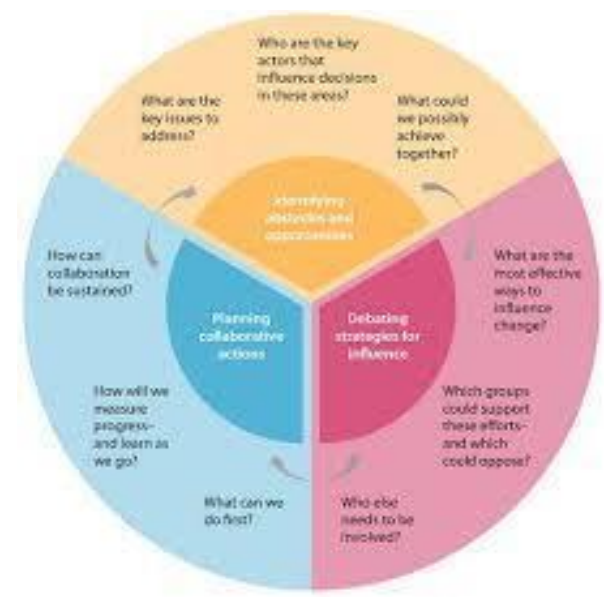

Figure 1, Collective Governance Stages (Ratner, 2012: 5)

Based on this picture, three stages of Collective Governance can be interpreted, based on the theory, namely:

1. Identifying Obstacles and Opportunities (identification of obstacles and opportunities)

The government, the private sector, the community and all stakeholders identify the problem condition map and the obstacles faced during the governance process of a program that is handled. This phase focuses on explaining the conditions of the problem between stakeholders and other stakeholders, listening to each other's problems explained by each stakeholder involved. Followed by predicting to solve possible problems, with the involvement of all stakeholders. Openness of each stakeholder occurs to listen to other parties so that they understand the problem map and opportunities for problem solving. 
2. Debating Strategies For Influence.

This phase focuses on dialogue or discussion between stakeholders or stakeholders regarding efforts to deal with obstacles, as well as the steps chosen to solve problems effectively and those who are involved in solving problems.

3. Planning Collaborative Actions (Phase of collaborative action plan)

This phase is marked by the efforts of stakeholders or policy makers involved to begin planning on the implementation of each strategy that has been carried out in the previous phase. This includes, among others, the initial steps to be taken in the collaboration process between stakeholders, identifying the measurement of each process carried out and determining the steps to maintain the collaboration process to continue in the long term.

\section{B. Disaster Risk Reduction}

Disaster Risk Reduction (DRR) is an important aspect of disaster preparedness, which is carried out at the Center and developed in the Regions. Local Governments have an important role to play in mobilizing various resources both to reduce disaster risk, through capacity building of policy implementing institutions, building community resilience, strengthening or complementing various risk reduction facilities (Indarti, et all, 2017)

\section{RESULTS AND DISCUSSION}

A. Earthquake and Tsunami PRBBK in Bengkulu City

1. The DRR program implemented in the period, namely:

\section{a. Disaster Preparedness School}

The PRB of the Earthquake and Tsunami in the City of Bengkulu was carried out within the scope of the school, in the form of a Disaster Preparedness School. Disaster Preparedness School as a school-based DRR program was developed by several institutions, which can complement and complement each other so that the school and all its components are resilient in dealing with disasters Disaster Preparedness Schools in the City of Bengkulu are carried out by several institutions, such as the Disaster Preparedness School in 2008 in collaboration with LIPI, Alert School Disaster of BPBD Bengkulu Province in 2009. Disaster / SAB Safe School collaborates with the Ministry of Education of Republic of Indonesia ... 
PMI fills the Disaster Preparedness School in collaboration with PMI Bengkulu Province with the German Red Cross (GRC) in 2009 (http: // www. Bengkulu-school-standbydisaster, 2009).

b. Disaster Risk Reduction Program in collaboration with the AID Program New Zealand, BNPB, UGM, GNS, UNIB and the Bengkulu Regional Disaster Management Agency (BPBD). This action developed various tools for DRR, which collaborated with various groups in the City of Bengkulu.

c. Community-Based Disaster Risk Reduction (PRBBK), consists of programs 1) Resilient Disaster Village (DESTANA)

DESTANA was developed by the Regional Disaster Management Agency, and the location of DESTANA which is a pioneer in the City of Bengkulu, has been carried out in Padang Serai (BPBD in Indarti et all: 2017)

2) Community Based Disaster Preparedness (KBBM)

This DRR program was developed by the Indonesian Red Cross (PMI), with a team of volunteers known to the people of Bengkulu City with the term SIBAT (Community Based Disaster Preparedness). The people of Bengkulu are more familiar with the term SIBAT PMI rather than the name of the program, KBBM, because this SIBAT moves a lot in DRR activities in the community

\section{3) TAGANA}

Disaster Preparedness Cadets (TAGANA) are disaster volunteers, coordinated by the Bengkulu Social Service. TAGANA was taken from the village residents, who carried out disaster and social humanitarian activities, and synergized with the Disaster Preparedness Village Program in their area in handling disasters, carrying out social activities and assisting humanitarian tasks.

The number of TAGANA in Bengkulu City is 184 people, spread in various villages in Bengkulu City. (Bengkulu Provincial Social Service, 2015). The distribution of TAGANA in urban villages varies in quantity

4) Active Alert Village

Basically Desa Alert is a village or kelurahan whose population has the readiness of resources, ability and willingness to prevent / overcome health problems, disasters and emergency, health independently. Initiation of Desa Siaga active in the City of 
Bengkulu is carried out by the Health Service, with the spearhead Puskesmas and RT cadres, who are directed to be independent in a botoom up manner.

5) Community-Based Disaster Risk Reduction (PRBBK) by Non-Governmental Organizations (NGOs)

The PRBBK in Bengkulu City was carried out through collaboration between NGOs and donor agencies such as USAID, German Red Cross (GRC), Japan Red Cross with locations including the Lempuing, Bawah, Teluk Sepang Villages.

\section{Management and Coordination}

DRR that is implemented has their own pattern, according to the program carried out. Coordination is carried out by various DRR implementing agencies, especially at the beginning of implementation and the end of implementation. Coordination that has been developed more intensively is the DRR program that was implemented in collaboration with the BPBD of Bengkulu City in collaboration with the AID Program in New Zealand, BNPB, UGM, GNS, UNIB. DRR management which has involved various satkeholders is feasible to be developed as a continuous implementation of DRR.

\section{B. COLLABORATIVE GOVERNANCE IN EARTHQUAKE AND TSUNAMI PRBBK IN}

\section{BENGKULU CITY}

Collaborative governance in the Reduction of Earthquake and Tsunami Risk in the city of

Bengkulu based on the stages of Ratner, can be described as follows:

\section{Identifying Obstacles and Opportunities}

The identification phase for DRR in Bengkulu City was initiated by the Regional Disaster Management Agency (BPBD) of the City of Bengkulu, by coordinating and dialogue, inviting the Provincial BPBD, academics, other services, companies and BUMN (PLN, Telkom and so on), PMI, NGOs, institutions donors and so on. This is targeted to be able to understand the problems in DRR, where each party has a concern to participate according to their potential and conditions. DRR issues that need attention, namely the development of DRR as a new paradigm are still limited, the participation of stakeholders is still incidental and there is no continuity, as well as for community-based DRRBBs that have only developed in limited villages, schools or institutions. Obstacles in earthquake and tsunami DRR namely the diversity of understanding of DRR implementation, 
bureaucratic culture that has not fully supported DRR performance, limited funds and collaborative funding, incidental collaboration between stakeholders, limited data base for disasters, difficulty in following up resources and sustainability of DRR. The focus of the problem that needs to be the starting point is the follow-up of DRR that needs to be developed with intensive collaboration from all stakeholders

Opportunities in solutions to DRR problem solving are found in the City BPBD as the initial initiation to follow up on DRR development that has been carried out to date. The Bengkulu City DRR Forum permanently needs to be formed and developed to synergize the diverse potential of stakeholders.

\section{Planning Collaborative Actions (Optional Phase)}

Stakeholders or policy makers involved in the implementation of DRR do planning on the implementation of each strategy that has been discussed, such as the initial steps to be taken in the process of collaboration between stakeholders.

These plans include measures to be taken by government agencies such as the City BPBD, CSR development of DRR-based government and private business entities, namely PLN, Telkom and other institutions in Bengkulu, actions by Universities and so on. There are limitations in this phase, where there is no identification of the measurement of each process carried out and there is no time schedule for action or steps to maintain the collaboration process to continue in the long term.

\section{Planning Collaborative Actions (Phase of collaborative action plan)}

The Collaborative Action Plan has been agreed with the DRR implementation strategy, both from government agencies, the private sector and Non-Governmental Organizations. Planning on the implementation of each strategy has been carried out globally, such as DRR socialization by each line, even up to socialization to communities and community leaders, such as DRR socialization through the Majelis Taklim forum and community meetings.

This action plan is still in its early stages, because there has been no intensive and ongoing evaluation, such as identifying measurements of each process carried out and determining steps to maintain the collaboration process to continue in the long term. 


\section{COVER}

Collaboration on DRR The earthquake and tsunami in the city of Bengkulu is still in

the pilot stage and provides an initial foundation for developing DRR policy

implementation

in the future. There are obstacles in the implementation and management of DRR, which requires strategic collaboration for the development of DRR effectively and equitably.

Strategies need to be developed so that each stakeholder has the same authority in determining the policies and actions of DRR implementation to follow DRR in the present

and future.

Permanent forum formation follow-up is needed flexibly, by avoiding a strict

hierarchical structure or using organization horizontally, so that it can accommodate and utilize various potential stakeholders optimally.

$* * * * * * * * * * * * * * * * * *$

\section{BIBLIOGRAPHY}

Ansell, Christopher, 2014, Pragmatist Democracy : Evolutionary Learning as Public Philosophy,New York: Oxford University Press, Inc

Ansell, Chris \& Alison Gash, 2007, Collaborative Governance in Theory and Practice,

Journal of Public Administration Research and Theory, Vol. 18 No. 4, Hal. 543-571

Dinas Sosial Provinsi Bengkulu, Surat Keputusan Kepala Dinas Kesejahteraan Sosial

Provinsi Bengkulu No. 22a/PSKBA/Diskesos.IV/2015 tentang Penunjukan Anggota Taruna

Siaga Bencana (TAGANA) Provinsi Bengkulu Tahun Anggaran 2015

Indarti.Sri, Switri.Sri, Suharyanto, Kismartini, Journal of social sience studies, ISSN

2329-9150, 2017, Vol. 4, No. 2 www.macrothink. org/ journal/index.php/jsss https://www.academia.edu/35726607/PROCEEDING_IAPA_INTERNATIONAL_CONFEREN

CE_2017_UNIVERSITAS_AIRLANGGA

http://www. kesekolah.com/artikel-dan-berita/ bengkulu-siapkan-3-sekolah-siaga-bencana 24 November 2009.

Ratner. 2012. Collaborative Governance Assessment. Malaysia: CGIAR

http://www. kesekolah.com/artikel-dan-berita/ bengkulu-siapkan-3-sekolah-siaga-bencana 24

November 2009. 